$\mathbb{T}$ periodica polytechnica

\author{
Transportation Engineering \\ $39 / 1(2011) 3133$ \\ doi: 10.3311/pp.tr.2011-1.06 \\ web: http://www.pp.bme.hu/tr \\ (c) Periodica Polytechnica 2011
}

RESEARCH ARTICLE

\section{International literature review on the possibilities of biodiesel production}

\author{
Ákos Bereczky / Ádám Török
}

Received 2011-03-03

\begin{abstract}
Continued use of petroleum-based fuels is now widely recognized as unsustainable because of depleting supplies and contribution of these fuels to pollute the environment. The challenge, therefore, is to secure adequate energy supplies at the least possible cost. Over 1.5 trillion barrels of oil equivalent have been produced since Edwin Drake drilled the world's first oil well in 1859. Economic growth is always accompanied by commensurate increase in the transport. The high energy demand in the industrialized world as well as in the domestic sector, and pollution problems caused due to the widespread use of fossil fuels make it increasingly necessary to develop the renewable energy sources of limitless duration and smaller environmental impact than the traditional one. One possible alternative to fossil fuel is the use of oils of plant origin like vegetable oils and non-edible oils. Usage of biodiesel will allow a balance to be sought between agriculture, economic development and the environment. The aim of this article is to investigate to hidden possibilities of biodiesel utilisation in Hungary by the review of international literature.
\end{abstract}

\section{Keywords}

diesel fuel $\cdot$ biodiesel

\section{Acknowledgement}

This research paper is a part of the scientific program of the "Development of Quality-Oriented and Harmonized $R+D+I$ Strategy and Functional Model at BME". The projects was supported by the New Széchenyi Development Plan: TÁMOP4.2.1/B-09/1/KMR-2010-0002. This paper is supported by Bólyai János Research fellowship of HAS (Hungarian Academy of Scinence).

\section{Ákos Bereczky}

Department of Transport Economics, BME, H-1111 Budapest Bertalan L. u. 2., Hungary

\section{Ádám Török}

Department of Transport Economics, BME, H-1111 Budapest Bertalan L. u. 2., Hungary

e-mail: atorok@kgazd.bme.hu

\section{Introduction}

The world has been confronted with an energy crisis due to depletion of limited resources of fossil fuel. Continued utilization of petroleum-based fuels is now widely recognized as unsustainable because of depleting supplies and contribution of these fuels to pollute the environment. The challenge is, therefore to secure adequate energy supplies at the least possible cost. Over 1.5 trillion barrels of oil equivalent have been produced since Edwin Drake drilled the world's first oil well in 1859. The world will need that same amount to meet demand in the next 25 years alone. The International Energy Agency has reported in the reference scenario that the world's primary energy need is projected to grow by $55 \%$ between 2005 and 2030, at an average annual rate of $1.8 \%$ per year. Fossil fuels remain the dominant source of primary energy, accounting for $84 \%$ of the overall increase in demand between 2005 and 2030 [1]. Energy and capital have reported that, by 2025 , the world's demand for oil will shoot up to $60 \%$, while production capacity would be thrown back to 1985 levels. According to the Energy Information Agency report, petroleum consumption fell by 90,000 barrels per day in 2008-2009. Transportation is one of the fastest growing sectors using $27 \%$ of the primary energy [1]. At the present staggering rates of consumption, the world fossil oil reserve will be exhausted in less than 45 years [2]. Majority of the worlds energy needs are supplied through petrochemical sources, coal and natural gases, and with the exception of hydroelectricity and nuclear energy, these sources are finite and at current usage rates will be consumed shortly [3]. Diesel fuels have an essential function in the industrial economy of a developing country and used for transport of industrial and agricultural goods and operation of diesel tractor and pump sets in agricultural sector. Economic growth is always accompanied by commensurate increase in the transport. The high energy demand and pollution problems caused due to the widespread use of fossil fuels make it necessary to develop renewable energy sources. This has stimulated recent interest in alternative sources for petroleum-based fuels. An alternative fuel must be technically feasible, economically competitive, environmentally acceptable, and readily available. One possible alternative to 
fossil fuel is the use of oils of plant origin like vegetable oils and non-edible oils. After chemical processes, like transesterification or hydrogenation this alternative diesel fuel can be termed as biodiesel. This fuel is biodegradable and non-toxic and has low emission profiles as compared to petroleum diesel. Usage of biodiesel will allow a balance to be sought between agriculture, economic development and the environment. Chemically the oils/fats consist of triglyceride molecules of three long chain fatty acids that are ester bonded to a single glycerol molecule. These fatty acids differ by the length of carbon chains, the number, orientation and position of double bonds in these chains. Thus biodiesel refers to lower alkyl esters of long chain fatty acids, which are synthesized either by transesterification with lower alcohols or by esterification of fatty acids. Thus, as far as the exploitation of diesel engines fuelled with diesel/biodiesel blends is well-known, the factfindings of the influence of ethanol additives on engine characteristics presented in the scientific papers are still discussed by many researchers [4]-[17], [53]. These facts have encouraged initiating research on the characteristics of the diesel engine fuelled with blends [8], [14]-[33], [51].

\section{Biodiesel}

The use of vegetable oils as alternative fuels has been around for 100 years when the inventor of the diesel engine Rudolph Diesel first tested peanut oil, in his compression ignition engine [30]. He said, "The use of vegetable oils for engine fuels may seem insignificant today. But such oils may in course of time be as important as petroleum and the coal tar products of the present time". However, due to cheap petroleum products, such non-conventional fuels never took off. Oils occupy a prominent position in the development of alternative fuels although, there have been many problems associated with using it directly in diesel engine (especially in direct injection engine). The main problem to the use of vegetable oils and especially animal fats are the high viscosity (about 11-17 times higher than diesel fuel), and lower volatilities that cause the formation of deposits in engines due incorrect vaporization characteristics to generate incomplete combustion. Other disadvantages:

- Coking and trumpet formation on the injectors to such an extent that fuel atomization does not occur properly or is even prevented as a result of plugged orifices,

- Lubricating problems of injection elements,

- Carbon deposits and oil ring sticking and,

- Thickening or gelling of the lubricating oil as a result of contamination by vegetable oils.

These problems are associated with the large size of the triglyceride molecule and its higher molecular mass and are avoided by modifying the engine less or more according to the conditions of use and the oil involved. The modified engines built by Elsbett in Germany and Malaysia and Diesel Morten und Geraetebau GmbH (DMS) in Germany and in the USA show a good performance when fuelled with vegetable oils of different composition and grades [3]. The plant oils usually contain free fatty acids, phospholipids, sterols, water, odourants and other impurities. Because of these, the oil cannot be used as fuel directly. To overcome these problems the oil requires slight chemical modification; mainly transesterification, hydrogenation, pyrolysis and emulsification. Among these, the transesterification is the key and foremost important step to produce a cleaner and environmentally safe fuel from vegetable oils. Biodiesel is the monoalkyl ester of long chain fatty acids derived from renewable feed stocks, such as vegetable oil or animal fats, for use in compression ignition engines. Biodiesel, which is considered as a possible substitute of conventional diesel fuel is commonly composed of fatty acid methyl esters that can be prepared from triglycerides in vegetable oils by transesterification with methanol. The resulting biodiesel is quite similar to conventional diesel fuel in its main characteristics. Due to the more aggressive chemical behaviour of bio-based additives to rubber and plastic parts of the fuel supply system, gaskets and fuel tank, it is recommendable to replace them with those resisting degradation [34].

\section{Fuel properties and specification of biodiesel}

In view of environmental considerations, biodiesel is considered as 'carbon neutral' because all the carbon dioxide $\left(\mathrm{CO}_{2}\right)$ released during consumption had been sequestered from the atmosphere for the growth of oil crops. Commercial experience with biodiesel has been very promising. The biggest advantages of biodiesel compared to many other alternative transportation fuels is that it can be used in existing diesel engines without modification, and can be blended with petroleum diesel in required ratio. Biodiesel performs as well as petroleum diesel, while reducing emissions of particulate matter, carbon monoxide (CO), hydrocarbons and oxides of sulphur $\left(\mathrm{SO}_{x}\right)$ [35]. Emissions of oxides of nitrogen $\left(\mathrm{NO}_{x}\right)$ are, however, higher for biodiesel in many, mainly direct injection engines. Biodiesel virtually eliminates the notorious black soot emissions associated with diesel engines and the total particulate matter emissions are also much lower. Other environmental benefits of biodiesel include the fact that it is highly biodegradable and appear to reduce emissions of air toxics and carcinogens (relative to petroleum diesel). The environmental benefits of $100 \%$ and $20 \%$ biodiesel blending, in term of pollutants emission reductions are shown in Table 1 . Usage of biodiesel will allow a balance to be sought between agriculture, economic development and the environment.

Since biodiesel is produced in quite differently scaled plants from vegetable oils of varying origin and quality, it was necessary to install a standardization of fuel quality to guarantee engine performance without any difficulties. Austria was the first country in the world to define and approve the standards for rapeseed oil methyl esters as diesel fuel. As standardization is a 
Tab. 1. Biodiesel vs. diesel emissions.

\begin{tabular}{|c|c|c|}
\hline Emissions & B100, pure biodiesel & B20, mixed biodiesel ( $20 \%$ biodiesel and $80 \%$ petroleum diesel) \\
\hline \multicolumn{3}{|l|}{ Regulated emissions (\%) } \\
\hline Total unburned hydrocarbons & -93 & -30 \\
\hline Carbon monoxide & -50 & -20 \\
\hline Particulate matter & -30 & -22 \\
\hline $\mathrm{NO}_{x}$ & +13 & +2 \\
\hline \multicolumn{3}{|l|}{ Non-regulated emissions (\%) } \\
\hline Sulphates & -100 & -20 \\
\hline Polycyclic aromatic hydrocarbons (PAHs) & -80 & -13 \\
\hline Nitrated PAHs (NPAHs) & -90 & -50 \\
\hline Ozone potential of $\mathrm{HC}$ & -50 & -10 \\
\hline \multicolumn{3}{|l|}{ Life cycle emissions (\%) } \\
\hline Carbon dioxide & -80 & \\
\hline Sulphur dioxide & -100 & \\
\hline
\end{tabular}

prerequisite for successful market introduction and penetration of biodiesel, standards or guidelines for the quality of biodiesel have also been defined in other countries like Germany, Italy, France, the Czech Republic and in the United States. The parameters, which define the quality of biodiesel, can be divided into two groups. One group contains general parameters, which are also used for petroleum based fuel, and the other group describes especially the chemical composition and purity of fatty acid alkyl esters [36]. Table 2 contains the general and Table 3 the oil specific parameters and the corresponding value of fatty acid methyl esters according to the standards of the above mentioned countries.

Among the general parameters for biodiesel, the viscosity controls the characteristics of the injection from the diesel injector. The viscosity of fatty acid methyl esters can reach higher levels and hence it is important to control it within an acceptable level to avoid negative impacts on the fuel injector system performance. Therefore, the viscosity specifications proposed are nearly the same as that of the diesel fuel. Flash point of a fuel is the temperature at which it will ignite when exposed to a flame or spark. The flash point of biodiesel is higher than that of the petrodiesel, which is safer for transport purposes. Cold filter plugging point (CFPP) of a fuel reflects its cold weather performance. At low operating temperature fuel may thicken and might not flow properly affecting the performance of fuel lines, fuel pumps and injectors. Normally either pour point or CFFP are specified. Pour point is the lowest temperature at which the oil specimen can still be moved. French and Italian biodiesel specifications specify pour point whereas others specify CFPP. Cetane number is indicative of its self ignition characteristics. The higher the cetane number are better the ignition properties. Cetane number affects a number of engine performance parameters like combustion, stability, driveability, white smoke, noise and emissions of $\mathrm{CO}$ and HC. Neutralization number is specified to ensure proper ageing properties of the fuel and/or a good manufacturing process. It reflects the presence of free fatty acids or acids used in manufacture of biodiesel and also the degradation of biodiesel due to thermal effects. Carbon residue of the fuel is indicative of carbon depositing tendencies of the fuel. Conradsons Carbon Residue for biodiesel is more important than for diesel fuel because it shows a high correlation with presence of free fatty acids, glycerides, soaps, polymers, higher unsaturated fatty acids and inorganic impurities. The presence of high level of alcohol in biodiesel causes accelerated deterioration of natural rubber seals and gaskets. Therefore control of alcohol content is required. Biodiesel fuel mainly consists of fatty acid alkyl esters and its quantities are specified according to the specifications of various countries. The presence of monodi- and triglycerides cause engine problems like fuel filter plugging affecting the fuel properties and are specified in most of the biodiesel standards.

\section{Biodiesel production from used cooking oil}

In most parts of the world edible oils are used in frying pans or fryers and after a variable time of use are discarded.. At present there is no systematic method of processing used oils from households and most of the used oil is mostly disposed of through home drains and ends up in wastewaters that are then discharged to surface waters, leading to water pollution. Moreover, more than $80 \%$ of the oil is consumed at home; the control of this disposal behavior becomes a huge problem because of the large volumes involved. Despite the gains made in biodiesel production techniques, the cost of biodiesel is still higher than petroleum-based diesel and this has been a major barrier to its commercialization. One of the ways widely accepted for reducing the cost focuses on minimizing the raw material cost. The use of waste cooking oil instead of virgin (neat) oil to produce biodiesel has been found to be an effective way to reduce the raw material cost. Hence reusing of the waste cooking oil has both the benefit of producing an environmentally benign fuel 
Tab. 2. General parameters of the quality of biodiesel

\begin{tabular}{|c|c|c|c|c|c|c|}
\hline Parameters & $\begin{array}{l}\text { Austria } \\
\text { (ON) }\end{array}$ & $\begin{array}{l}\text { Czech } \\
\text { (CSN) }\end{array}$ & $\begin{array}{l}\text { France } \\
\text { (journal official) }\end{array}$ & Germany (DIN) & Italy (UNI) & USA (ASTM) \\
\hline Density at $15^{\circ} \mathrm{C}\left[\mathrm{g} / \mathrm{cm}^{3}\right]$ & $0.85-0.89$ & $0.87-0.89$ & $0.87-0.89$ & $0.875-0.89$ & $0.86-0.90$ & - \\
\hline Viscosity at $40\left[\mathrm{~mm}^{2} / \mathrm{s}\right]$ & $3.5-5.0$ & $3.5-5.0$ & $3.5-5.0$ & $3.5-5.0$ & $3.5-5.0$ & $1.9-6.0$ \\
\hline Flash point $\left[{ }^{\circ} \mathrm{C}\right]$ & 100 & 110 & 100 & 110 & 100 & 130 \\
\hline $\mathrm{CFPP}\left[{ }^{\circ} \mathrm{C}\right]$ & $0 /-5$ & -5 & - & $0-10 /-20$ & - & - \\
\hline Pour point $\left[{ }^{\circ} \mathrm{C}\right]$ & - & - & -10 & - & $0 /-5$ & - \\
\hline Cetane number & $\geq 49$ & $\geq 48$ & $\geq 49$ & $\geq 49$ & - & $\geq 47$ \\
\hline Neutralization number $[\mathrm{mgKOH} / \mathrm{g}]$ & $\leq 0.8$ & $\leq 0.5$ & $\leq 0.5$ & $\leq 0.5$ & $\leq 0.5$ & $\leq 0.8$ \\
\hline Conradson carbon residue [\%] & 0.05 & 0.05 & - & 0.05 & - & 0.05 \\
\hline
\end{tabular}

Tab. 3. Vegetable oil specific parameters for the quality of biodiesel

\begin{tabular}{|c|c|c|c|c|c|c|c|c|}
\hline Parameters & $\begin{array}{l}\text { Austria } \\
\text { (ON) }\end{array}$ & $\begin{array}{l}\text { Czech } \\
\text { (CSN) }\end{array}$ & Republic & $\begin{array}{l}\text { France } \\
\text { official) }\end{array}$ & (journal & Germany (DIN) & Italy (UNI) & USA (ASTM) \\
\hline Methanol/ethanol (\% mass) & $\leq 0.2$ & - & & $\leq 0.1$ & & $\leq 0.3$ & $\leq 0.2$ & - \\
\hline Ester content (\% mass) & - & - & & $\geq 96.5$ & & - & $\geq 98$ & - \\
\hline Monoglyceride (\% mass) & - & - & & $\leq 0.8$ & & $\leq 0.8$ & $\leq 0.8$ & - \\
\hline Diglyceride (\% mass) & - & - & & $\leq 0.2$ & & $\leq 0.4$ & $\leq 0.2$ & - \\
\hline Triglyceride (\% mass) & - & - & & $\leq 0.2$ & & $\leq 0.4$ & $\leq 0.1$ & - \\
\hline Free glycerol (\% mass) & $\leq 0.02$ & $\leq 0.02$ & & $\leq 0.02$ & & $\leq 0.02$ & $\leq 0.05$ & $\leq 0.02$ \\
\hline Total glycerol (\% mass) & $\leq 0.24$ & $\leq 0.24$ & & $\leq 0.25$ & & $\leq 0.25$ & - & $\leq 0.24$ \\
\hline lodine number & $\leq 120$ & - & & $\leq 115$ & & $\leq 115$ & - & - \\
\hline
\end{tabular}

Source: 52.

and solving the problem of waste oil disposal. The methods of production of biodiesel from used cooking oil do not differ from the conventional transesterification process using alkaline, acidic, and enzymatic catalysts. Depending on the undesirable compounds (especially FFA and water), each catalyst has its advantages and disadvantages. These used frying oils have different properties from those of refined and crude vegetable oils. The presence of heat and water accelerates the hydrolysis of triglycerides and increases the content of free fatty acids (FFA) in the oil [37]. The FFA and water content have significant negative effects on the transesterification reaction [38]. They also interfere with the separation of fatty acid esters and glycerol. Especially, the viscosity of the oil increases considerably, because of the formation of dimeric and polymeric acids and glycerides in used cooking oils. Molecular mass and iodine values decrease while saponification value and density increase [37]-[39]. A typical schematic diagram for the production of biodiesel from used cooking oil is shown in Fig. 1

\section{Microalgae are emerging feedstock for biodiesel pro- duction}

Algae are very important from an ecological point of view. Algae are the food source for many animals and belonging to the bottom of the food chain; moreover, they are the principle producers of oxygen on earth. Their important role as food source is due to the content of minerals, vitamins and oils, rich in polyunsaturated fatty acids (PUFAs). PUFAs such as a-linolenic, eicosapentaenoic and docosaesaenoic acids, belong to the $\mathrm{v}-3$ group
[40]. Algae having the ability to synthesize TAGs are considered as a second generation feedstock for production of biofuels, specifically biodiesel. The potential value of microalgal photosynthesis to produce biofuels is widely recognized [41]-[44]. The advantages of microalgae over higher plants as a source of transportation biofuels are numerous:

1 Microalgae synthesize and accumulate large quantities of neutral lipids/oil [20-50\% dry cell weight (DCW)] and grow at high rates (e.g. 1-3 doublings/day).

2 Oil yield per area of microalgae cultures could greatly exceed the yield of best oilseed crops.

3 Microalgae can be cultivated in saline/brackish water/coastal seawater on non-arable land, and do not compete for resources with conventional agriculture.

4 Microalgae tolerate marginal lands (e.g. desert, arid and semiarid lands) that are not suitable for conventional agriculture.

5 Microalgae utilize nitrogen and phosphorus from a variety of wastewater sources (e.g. agricultural run-off, concentrated animal feed operations, and industrial and municipal wastewaters), providing the additional benefit of wastewater bioremediation.

6 Microalgae sequester $\mathrm{CO}_{2}$ from flue gases emitted from fossil fuel-fired power plants and other sources, thereby reducing emissions of a major greenhouse gas. $1 \mathrm{~kg}$ of algal biomass requires about $1.8 \mathrm{~kg}$ of $\mathrm{CO}_{2}$ [43]. 


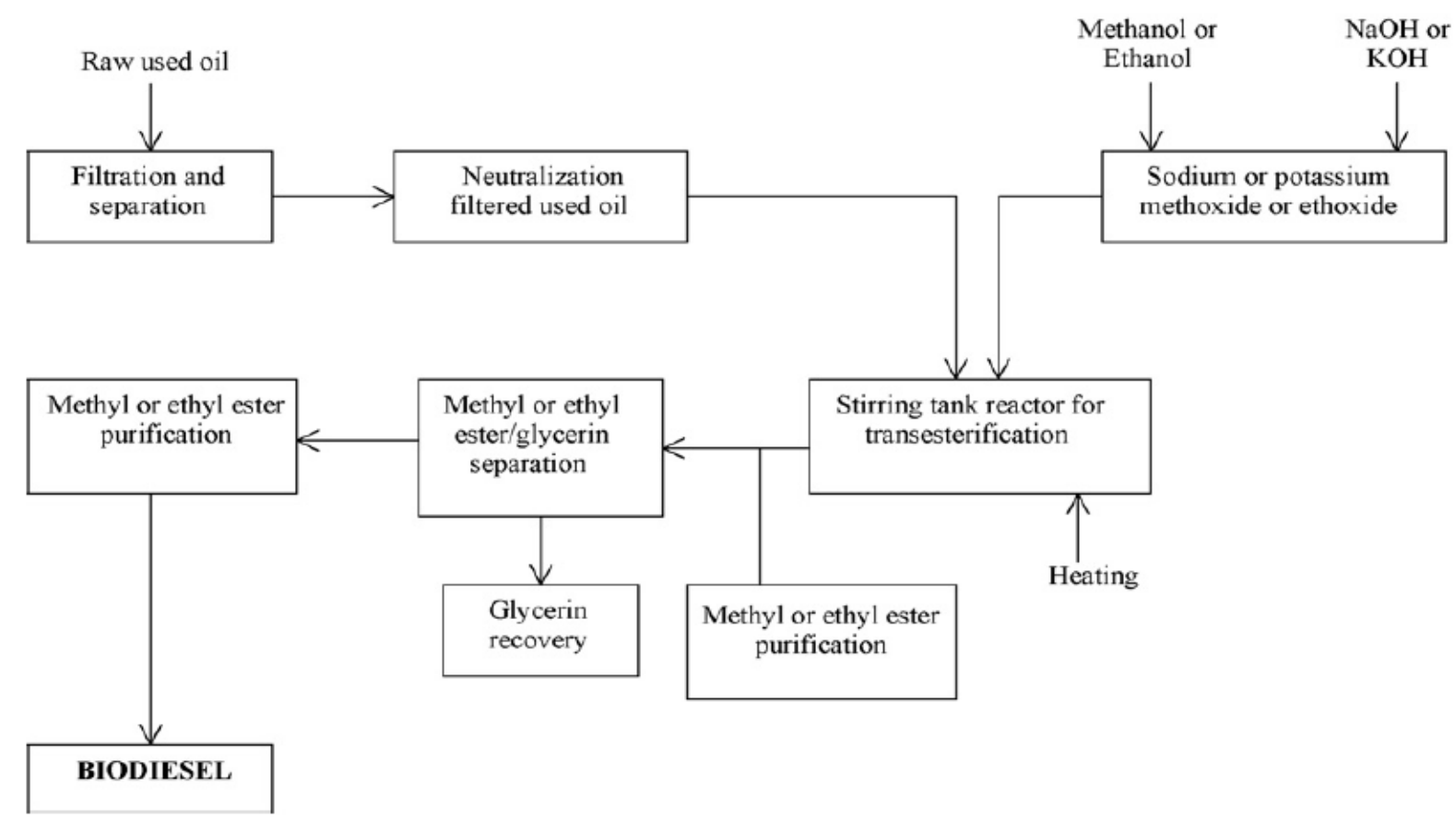

Fig. 1. Schematic flow diagram of the bio-diesel production from used cooking oil source: [54]

7 Microalgae produce value-added co-products or by-products (e.g. biopolymers, proteins, polysaccharides, pigments, animal feed and fertilizer) and does not need herbicide and pesticide.

8 Microalgae grow in suitable culture vessels (photobioreactors) throughout the year with higher annual biomass productivity on an area basis.

Microalgae can provide several different types of renewable biofuels. These include methane produced by anaerobic digestion of the algal biomass biodiesel derived from microalgal oil, [45]-[46] and photobiologically produced biohydrogen [47][48]. The idea of using microalgae as a source of fuel is not new but it is now being taken seriously because of the rising price of petroleum and, more significantly, the emerging concern about global warming that is associated with burning of fossil fuels [46]. Using microalgae to produce biodiesel will not compromise production of food, fodder and other products derived from crops. A comparison of some sources of crop oil is given in Table 4

In view of Table 4, microalgae appear to be the only source of biodiesel that has the potential to completely displace fossil diesel. Oil content in microalgae can exceed $80 \%$ by weight of dry biomass [45-46, 51]. Oil levels of $20-50 \%$ are quite common . Oil productivity, that is the mass of oil produced per unit volume of the microalgal broth per day, depends on the algal growth rate and the oil content of the biomass. Using microalgae also has the potential to avoid the controversies around the alternative fuel goals of the EU (competition for arable land, water footprint, etc.) [55].
Tab. 4. Comparison of algae with different crops for biofuel.

\begin{tabular}{ll}
\hline Source & $\begin{array}{l}\text { Liter of oil per } \\
\text { hectare per year }\end{array}$ \\
\hline Algae & $46700-187000$ \\
\hline Oil palm & 5940 \\
\hline Coconut & 2685 \\
\hline Jatropha & 1936 \\
\hline Rapeseed/Canola & 1188 \\
\hline Peanut & 1057 \\
\hline Sunflower & 954 \\
\hline Safflower & 776 \\
\hline Soybeans & 449 \\
\hline Hemp & 365 \\
\hline Corn & 168 \\
\hline Source: &
\end{tabular}

\section{Conclusion}

Under the existing EU standards, petrol and diesel shall contain biocomponents; moreover, it is required that the content of such biocomponents shall be continuously increased. The use of alternative fuels or their components is also promoted. Alternative fuels are defined as any materials or substances produced from renewable sources that can substitute petroleum fuels or any part thereof and are used for the purposes of economy and with a view to reducing pollution caused by transport. The fuels of biological origin mixed with conventional fuels or added thereto as individual components are the most frequently used type of alternative fuels.

The quality of biodiesel is most important from an engine point of view and various standards have been specified to check the quality. At the present moment, biofuels are derived from food crops such as sugarcane, sugar beet, maize 
(corn), sorghum, rapeseed, sunflower, soybean and palm, although other forms of biomass can be used, and may be preferable. The most significant concern is the inefficiency and sustainability of these first generation biofuels. In contrast, the second generation biofuels are derived from non-food feedstock. They are extracted from microalgae and other microbial sources, lignocellulosic biomass, rice straw and bioethers, and are a better option for addressing the food and energy security and environmental concerns [42, 56].

\section{References}

1 The International Energy Agency (IEA), World Energy Outlook 2007.

2 BP Statistical Review of the world energy, June 2008.

3 Srivastava A, Prasad R, Triglycerides-based diesel fuels, Renew Sustain Energy Rev (2000), no. 4, 111-33.

4 Shi X, Yu Y, He H, Shuai S, Wang J, Li R, Emission characteristics using methyl soyate-ethanol-diesel fuel blends on a diesel engine, Fuel 84 (2005), no. 12-13, 1543-1549.

5 Shi X, Pang X, Mu Y, He H, Shuai S, Wang J, Chen H, Li R, Emission reduction potential of using ethanol-biodiesel-diesel fuel blend on heavyduty diesel engine, Atmospheric Environment 40 (2006), no. 14, 2567-2574, DOI 10.1016/j. atmosenv.2005.12.026.

6 Pagowski Z T, New perspectives for biofuels in aviation, Journal of KONES 10 ( 2003), no. 3-4, 4, available at http://www.ilot.edu.pl/KONES/ 2003/3-4/28.pdf

7 Lebedevas S, Vaicekauskas A, Lebedeva G, Janulis P, Makarevicienë $\mathbf{V}$, Research into operational parameters of diesel engines running on RME biodiesel, Transport 21 (2006), no. 4, 260-268.

8 Lebedevas S, Vaicekauskas A, Suškov P, Presumptions of effective operation of diesel engines running on RME biodiesel, Research on kinetics of combustion of RME biodiesel, Transport 22 (2007), no. 2, 126-133.

9 Pikūnas A, Pukalskas S, Bureika G, Grabys J, Investigation of effi ciency of consuming ethanol of diesel engine, Journal of KONES 13 ( 2006), no. 2, 381-386.

10 Labeckas G, Reduction of environmentally harmful exhaust emissions by improving the performance process of diesel engines, 2005. Summary of the review of scientific works presented for Dr Habil procedure: technological sciences T000, environmental engineering and landscape management Lithuanian university of agriculture.

11 Raslavičius L, Research into three-component combustible mixture application for fuelling diesel engines, 2009. Summary of Doctoral Dissertation. Kaunas: Technologija.

12 Raslavičius L, Markšaitis D, Research into three-component biodiesel fuels combustion process using a single droplet technique, Transport 22 ( 2007), no. 4, 312-315.

13 Mittelbach M, Remschmidt C, Biodiesel: a Comprehensive Handbook, Graz, Austria, 2004.

14 Kwanchareon P, Luengnaruemitchai A, Jai-In S, Solubility of a dieselbiodiesel-ethanol blend, its fuel properties, and its emission characteristics from diesel engine, Fuel 86 (2007), no. 7-8, 1053-1061, DOI 10.1016/j.fuel.2006.09.034.

15 Bazaras Ž, Raslavičius L, Investigation of three-component biodiesel fuels using a single droplet technique, Proceedings of the 7th International Conference Vibroengineering 2008, October 9-11, Kaunas, Lithuania, 2008, pp. 109-112.

16 Török Á, Theoretical estimation of the environmental impact of biofuel mixtures, Transport 24 (2009), no. 1, 26-29, DOI 10.3846/16484142.2009.24.26-29.

17 Al-Hasan M I, The effect of iso-butanol-diesel blends on engine per- formance, Transport 23 (2008), no. 4, 306-310, DOI 10.3846/16484142.2008.23.306-310.

18 Jeuland N, Montagne X, Gautrot X, Potentiality of ethanol as a fuel for dedicated engine, Oil \& Gas Science and Technology - Rev. IFP 59 (2004), no. 6, 559-570.

19 Li D G, Zhen H, Xingcai L, Wu-Gao Z, Jian-Guang Y, Physico-chemical properties of ethanol-diesel blend fuel and its effect on performance and emissions of diesel engines, Renewable Energy 30 ( 2005), no. 6, 967-976, DOI 10.1016/j.renene.2004.07.010.

20 Makarevičiené V, Sendžikienë E, Janulis P, Solubility in multicomponent biodiesel fuel systems, Bioresource Technology 96 ( 2005), no. 5, 611-61, DOI 10.1016/j.biortech.2004.06.007.

21 Thirouard B, Cherel J, Nature of CAI combustion and air/fuel ratio stratifi cation effects, Oil \& Gas Science and Technology - Rev. IFP 61 (2006), no. $1,95-119$.

22 Agarwal A K, Biofuels (alcohols and biodiesel) applications as fuels for internal combustion engines, Progress in Energy and Combustion Science 33 ( 2007), no. 3, 233-271, DOI 10.1016/j.pecs.2006.08.003.

23 Albrecht A, Grondin O, Le Berr F, Le Solliec G, Towards a stronger simulation support for engine control design: a methodological point of view, Oil \& Gas Science and Technology - Rev. IFP 62 (2007), no. 4, 437-456.

24 Arsie I, Pianese C, Sorrentino M, Effects of control parameters on performance and emissions of HSDI diesel engines: investigation via two zone modeling, Oil \& Gas Science and Technology - Rev. IFP 62 (2007), no. 4, 457-469.

25 Butkus A, Pukalskas S, Bogdanovicius Z, The influense of turpentine additive on the ecological parameters of diesel engines, Transport 22 (2007), no. 2, 80-82.

26 Lebedevas S, Vaicekauskas A, Lebedeva G, Makarevičiené V, Janulis $\mathbf{P}$, Change in operational characteristics of diesel engines running on RME biodiesel fuel, Energy \& Fuels 21 (2007), no. 5, 3010-3016, DOI 10.1021/ef060314t.

27 Boychenko S, Shkilnuk I, Turchak V, The problems of biopollution with jet fuels and the way of achieving solution, Transport 23 (2008), no. 3, 253257.

28 Lingaitis L P, Pukalskas S, Ecological aspects of using biological diesel oil in railway transport, Transport 23 (2008), no. 2, 138-143.

29 Lebedevas S, Lebedeva G, The problems of using alcohol biofuel mixtures in the Lithuanian transport system, Transport 24 (2009), no. 1, 58-65, DOI 10.3846/1648-4142.2009.24.58-65.

30 Petrovič J, Ivkovič I, Vujačič I, Žeželj S, Possibilities of buses on alternative fuel in public urban transport in Belgrade, Technological and Economic Development of Economy 15 ( 2009), no. 1, 78-89, DOI 10.3846/13928619.2009.15.78-89

31 Jonas Matijošius, Edgar Sokolovskij, Research into the quality of fuels and their biocomponents, TRANSPORT 24 (2009), no. 3, 212-217, DOI 10.3846/1648-4142.2009.24.212-217.

32 Laurencas Raslavičius, Žilvinas Bazaras, The analysis of the motor characteristics of D-RME-E fuel blend during on-field tests, Transport 24 (2009), no. 3, 187-191, DOI 10.3846/1648-4142.2009.24.187-191, available at www.transport.vgtu.lt

33 Barnwal B K, Sharma M P, Prospects of biodiesel production from vegetable oils in India, Renew Sust Energy Rev 9 (2005), 363-78.

34 Mittelbach M, Diesel fuel derived from vegetable oils, VI: Specifications and quality control of biodiesel, Bioresour Technol 27 (1996), no. 5, 435-7.

35 Marmesat S, Rodri'guez-Macado E, Velasco J, Dorbangarnes M C, Used frying fats and oils: comparison of rapid tests based on chemical and physical oil properties, Int J Food Sci Technol 42 (2007), 601-8.

36 Canakci M, Özsezen A N, Evaluating waste cooking oil as alternative diesel fuel, GU J Sci 18 (2005), no. 1, 81-91. 
37 Tomasevic A V, Marinkovic S S, Methanolysis of used frying oils. Fuel Process Technol 81 (2003), 1-6.

38 Kulkarni MG, Dalai A K, Waste cooking oil-an economical source for biodiesel: a review., Ind Eng Chem Res 45 (2006), 2901-13.

39 Ruiz-Mendes M V, Marmesat S, Liotta A, Dobarganes M C, Analysis of used frying fats for the production of biodiesel., Grasas y Aceites 59 (2008), no. $1,45-50$.

40 Schenk PM, Thomas-Hall SR, Stephens E, Marx UC, Mussgnug JH, Posten C, Second generation biofuels: high-efficiency microalgae for biodiesel production, Bioenerg Res ( 2008), no. 1, 20-43.

41 Rodolfi L, Zittelli C G, Bassi N, Padovani G, Biondi N, Biondi G, $M i$ croalgae for oil: strain selection, induction of lipid synthesis and outdoor mass cultivation in a low cost photobioreactor., Biotechnol Bioeng 102 ( 2009), no. 1, 100-12.

42 Patil V, Tran K Q, Giselrod H R, Towards sustainable production of biofuels from microalgae, Int J Mol Sci 9 ( 2008), 1188-95.

43 Banerjee A, Sharma R, Chisti Y, Banerjee UC, Botryococcus braunii: a renewable source of hydrocarbons and other chemicals, Crit Rev Biotechnol 22 ( 2002), 245-79.

44 Gavrilescu M, Chisti Y, Biotechnology-a sustainable alternative for chemical industry, Biotechnol Adv 23 (2005), 471-99.

45 Fedorov AS, Kosourov S, Ghirardi ML, Seibert M, Continuous H2 photo production by Chlamydomonas reinhardtii using a novel two-stage, sulfatelimited chemostat system, Appl Biochem Biotechnol (2005), 403-12.

46 Kapdan IK, Kargi F, Biohydrogen production from waste materials, Enzyme Microb Technol 38 (2006), 569-82.

47 Metzger P, Largeau C, Botryococcus braunii: a rich source for hydrocarbons and related ether lipids, Appl Microbiol Biotechnol 66 ( 2005), 486-96.

48 Kondili EM, Kaldellis J K, Biofuel implementation in East Europe: current status and future prospects, Renew Sust Energy Rev 11 (2007), 2137-51.

49 Ragauskas AJ, Williams CK, Davison BH, Britovsek G, Cairney J, Eckert CA, The path forward for biofuels and biomaterials, Science 311 (2006), 484-9.

50 S.A. Khan, Prospects of biodiesel production from microalgae in India, Renewable and. Sustainable Energy Reviews 13 ( 2009), 2361-2372.

51 Zöldy M, Potential future renewable fuel challanges for internal combustion engine, Jármúvek és Mobilgépek, II.évf., 2009, pp. 397-403.

52 Meher L C, Technical aspects of biodiesel production by transesterification - a review, Renewable and Sustainable Energy Reviews 10 (2006), no. 3, 248-268, DOI 10.1016/j.rser.2004.09.002.

53 Zöldy M, Significance of application technique of fuel containing biocomponents (2009), no. 3, 133-139. MOL SZTK HSE különszám.

54 Enweremadu C C, Mbarawa M M, Technical aspects of production and analysis of biodiesel from used cooking oil - A review, Renew Sustain Energy Rev, posted on 2009, DOI 10.1016/j.rser.2009.06.007., (to appear in print).

55 Szendro G, Sustainable biofuels in Hungary and Europe - self-defeating incentives?, Gazdálkodás Scientific Journal On Agricultural Economics (June 2010), 71-79. English Special Edition.

56 Zöldy M, Holló A, Thernesz A, Butanol as diesel extender option for internal combustion engine, SAE World Congress 2010. Paper Number: 10SDP0015 . 